Copying. This journal is registered with the Copyright Clearance Center, 27 Congress Street, Salem, Mass. 01970. Organizations in the USA who are also registered with C.C.C. may therefore copy material (beyond the limits permitted by sections 107 and 108 of the US copyright law) subject to payment to C.C.C. of the per-copy fee of $\$ 5.00$. This consent does not extend to multiple copying for promotional or commercial purposes. Code 0007-1145/92 $\$ 5.00+.00$.

ISI Tear Sheet Service, 3501 Market Street, Philadelphia, Pennsylvania 19104, USA, is authorized to supply single copies of separate articles for private use only.

For all other use, permission should be sought from Cambridge or the American Branch of Cambridge University Press.

The Proceedings of the Nutrition Society, published by the Cambridge University Press, in part record meetings of the Symposium type, at which experts in a particular field are invited by Council to make contributions on specific parts of it and at which general discussion follows these invited contributions. The contributions will be published in extenso; such summaries of the ensuing discussions as circumstances warrant may also be published. The Society also holds scientific meetings at which papers are communicated by members and others on original work carried out by them. It is proposed at present to publish summaries of the papers read at each meeting, each communication being recorded in the Society's Proceedings by means of an abstract not exceeding in length 400 words or the equivalent space in print. The Proceedings are published three times a year.

The subscription to the Proceedings is $£ 103.00$ net (US \$204.00 in USA and Canada). Single issues are $£ 36.00$ (US $\$ 71.00$ in the USA and Canada) each; postage extra.

\begin{tabular}{|c|c|c|}
\hline & & INDEX OF A \\
\hline Annison, G. & 123 & $\begin{array}{l}\text { Gidenne, T. } \\
\text { Goodwin, B. F. J. }\end{array}$ \\
\hline Barth, C. A. & 67 & \\
\hline Broderick, G. A. & 27 & $\begin{array}{l}\text { Hemilä, H. O. } \\
\text { Higham, S. E. }\end{array}$ \\
\hline Choct, M. & 123 & \\
\hline Clayton, M. K. & 27 & Keller, B. \\
\hline Crevel, R. W. R. & 17 & Longstaff $M$ \\
\hline Eichinger, $\mathrm{H}$. & 43 & McCorquodale, C. \\
\hline Friend, J. V. & 17 & Metges, C. C. \\
\hline
\end{tabular}

$S$

133

17

3

115

Read, N. W.

Parish, W. E.

17

115

Schmidt, H.-L. 43

67 Southgate, D. A. T. 1

57 de Vrese, M. 67

57 Yuste, P. 57 


\section{The British]ournal of Nutrition}

\section{CONTENTS}

\section{Editorial}

The development of nutritional concepts. D. A. T. Southgate

\section{Nutritional Epidemiology}

Vitamin $\mathrm{C}$ and the common cold. Harri O. Hemila

Diet and the Immune Response

High-fat diets and the immune response of C57 BI mice. R. W. R. Crevel, J. V. Friend, B. F. J. Goodwin \& W. E. Parish

\section{Protein Degradation in the Rumen}

Rumen protein degradation rates estimated by non-linear regression analysis of Michaelis-Menten in vitro data. Glen A. Broderick \& Murray K. Clayton

\section{Metabolism in the Young Calf}

Use of naturally enriched mixed food in ${ }^{13} \mathrm{C}$ breath tests applied in young sucking calves. Cornelia C. Metges, Hanns-Ludwig Schmidt \& Hans Eichinger

\section{Dietary Effects on Intestinal Digestion}

The effect of proanthocyanidin-rich hulls and proanthocyanidin extracts from bean hulls (Vicia faba L.) on nutrient digestibility and digestive enzyme activities in young chicks. P. Yuste, M. Longstaff \& C. McCorquodale

Enhancement of intestinal hydrolysis of lactose by microbial $\beta$-galactosidase of kefir. Michael de Vrese, Birgit Keller \& Christian A. Barth

\section{Effects of Complex Carbohydrates on Nutrient Absorption}

Gastrointestinal morphology and absorption of monosaccharides in fowls conditioned to different types and levels of dietary fibre. C. J. Savory

Enzyme supplementation, degradation and metabolism of three $\mathrm{U}-{ }^{14} \mathrm{C}$-labelled cellwall substrates in the fowl. C. J. Savory

Metabolic fates of $\mathrm{U}-{ }^{14} \mathrm{C}$-labelled monosaccharides and an enzyme-treated cellwall substrate in the fowl. C. J. Savory

The effect of ingestion of guar gum on ileostomy effluent. S. E. Higham \& N.W. Read

The inhibition of nutrient digestion by wheat pentosans. M. Choct \& G. Annison 123-132

Effect of fibre level, particle size and adaptation period on digestibility and rate of passage as measured at the ileum and in the faeces in the adult rabbit. T. Gidenne

For Index of Authors see inside back cover

\section{CAMBRIDGE UNIVERSITY PRESS}

The Pitt Building, Trumpington Street, Cambridge CB2 1RP

40 West 20th Street, New York, NY 10011-4211, USA

10 Stamford Road, Oakleigh, Victoria 3166, Australia

Printed in Great Britain by the University Press, Cambridge 